\title{
MODEL PEMBELAJARAN KOOPERATIF TIPE JIGSAW UNTUK MENINGKATKAN PRESTASI BELAJAR BAHASA INDONESIA SISWA SMPN 1 BINTAN
}

\author{
Ninik Eka Widiastuty \\ Guru SMP Negeri 1 Bintan Kepulauan Riau \\ Email: ninikekawidiastuty@gmail.com
}

\begin{abstract}
Abstrak
Penelitian ini bertujuan untuk meningkatkan prestasi belajar bahasa Indonesia siswa pada materi cerita fantasi. Usaha meningkatkan prestasi belajar siswa dilakukan dengan menggunakan model pembelajaran kooperatif tipe jigsaw. Jenis penelitian ini adalah penelitian tindakan kelas (action reserach). Terdiri dari dua siklus yang meliputi: perencanaan tindakan, pelaksanaan tindakan, obsevasi dan refleksi. Subjek penelitian adalah siswa kelas VII G SMP Negeri 1 Bintan yang berjumlah 31 siswa. Penelitian dilaksanakan pada semester I tahun ajaran 2019-2020. Untuk mengumpulkan data hasil penelitian digunakan tes prestasi belajar dan untuk menganalisis datanya digunakan analisis deskriptif kualitatif. Dilihat dari hasil evaluasi yang telah dilakukan terjadi peningkatan dari data awal dengan rata-rata 63,87 , ketuntasan belajar $41,94 \%$, pada siklus I rata-ratanya 68,87 meningkat menjadi 77,10 dengan ketuntasan belajar $83,87 \%$, dengan demikian dapat disampaikan simpulan bahwa penerapan model pembelajaran kooperatif tipe jigsaw dapat meningkatkan prestasi belajar peserta didik.
\end{abstract}

\section{Kata kunci: Model Pembelajaran Tipe Jigsaw, Prestasi Belajar}

\section{PENDAHULUAN}

Pembelajaran merupakan usaha sadar dari pendidik agar peserta didik dapat mengenal dan memahami apa yang sedang dipelajarinya dengan cara mengajak peserta didik untuk berfikir (Darsono, 2000:40). Pembelajaran Bahasa Indonesia sebaiknya dilaksanakan dengan mengutamakan kemampuan berpikir, bekerja, merasakan, sikap sosial serta memberikan pengalaman belajar secara langsung guna meningkatkan pemahaman tentang materi yang dipelajari. Pengalaman belajar yang bermakna sangat dibutuhkan di dalam pembelajaran Bahasa Indonesia, karena siswa dapat mencari, mencoba, menemukan, serta mengalami sendiri materi pelajaran yang berguna dan diperlukan dalam kehidupan seharihari.

Apabila guru menguasai dan mengerti tentang hal-hal tersebut dapat diyakini bahwa prestasi belajar peserta didik pada mata pelajaran Bahasa Indonesia tidak akan rendah. Namun kenyataannya prestasi belajar siswa kelas VII.G tahun pelajaran 2019/2020 baru mencapai rata-rata 63,87

Melihat kesenjangan ini, dalam upaya memperbaiki mutu pendidikan utamanya pada mata pelajaran Bahasa Indonesia sangat perlu kiranya dilakukan perbaikan cara pembelajaran. Salah satunya adalah perbaikan pembelajaran dengan menggunakan model pembelajaran tipe Jigsaw.

Penggunaan model-model pembelajaran merupakan hal yang sangat penting dalam upaya memajukan suatu bidang tertentu. Model sangat berkaitan dengan teori. Model merupakan suatu analog konseptual yang digunakan untuk menyarankan bagaimana meneruskan penelitian empiris sebaiknya tentang suatu masalah. Jadi model merupakan suatu struktur konseptual yang telah berhasil dikembangkan dalam suatu bidang dan sekarang diterapkan, terutama untuk membimbing penelitian dan berpikir dalam bidang lain, biasanya dalam bidang yang belum begitu berkembang (Mark 1976 dalam Ratna Wilis Dahar, 1989: 5).

Tujuan Penelitian Tindakan Kelas adalah untuk mengetahui seberapa tinggi peningkatan prestasi belajar siswa melalui pembelajaran dengan penggunaan model pembelajaran kooperatif tipe jigsaw.

Teori yang melandasi pembelajaran cooperative learning adalah teori konstruktivisme. Pada dasarnya, pendekatan teori konstruktivisme dalam belajar adalah suatu pendekatan dimana siswa harus secara 
individual

menemukan

dan menstransformasikan informasi yang kompleks, memeriksa informasi dengan aturan yang ada dan merevisi nya bila perlu Soejadi dalam Teti Sobari dalam Rusman (2014, h.201). Menurut Slavin dalam Rusman (2014, h. 201), pembelajaran kooperatif menggalakkan siswa berinteraksi secara aktif dan positif dalam kelompok.

Metode mengajar tipe jigsaw dikembangkan oleh Aronson et al. sebagai model Cooperative Learning. Teknik ini bisa digunakan dalam pembelajaran membaca, menulis, mendengarkan, ataupun berbicara. Teknik ini menggabungkan kegiatan membaca, menulis, mendengarkan, dan berbicara. Pendekatan ini bisa pula digunakan dalam beberapa mata pelajaran, seperti ilmu pengetahuan alam, ilmu pengetahuan sosial, matematika, agama, dan bahasa. Teknik ini cocok untuk semua kelas/tingkatan (Lie, 2002: 68).

Dalam teknik ini, guru memperhatikan skemata atau latar belakang pengalaman siswa dan membantu siswa mengaktifkan skemata ini agar bahan pelajaran menjadi lebih bermakna (meaningful). Selain itu, siswa bekerja dengan sesama siswa dalam suasana gotong royong dan mempunyai banyak kesempatan untuk mengolah informasi dan meningkatkan keterampilan berkomunikasi.

Menurut Hilke (1998:10), pengembangan metode belajar kooperatif model jigsaw oleh Aronson sebetulnya menggunakan spesialisasi tugas. Masing-masing siswa mempunyai sebuah tugas yang berkontribusi untuk keseluruhan tujuan kelompok. Pada yang heterogen dari tiga sampai lima siswa, masing-masing siswa bekerja secara bebas untuk menjadi ahli terhadap bagian pelajaran tersebut dan dapat bertanggungjawab untuk mengajarkan informasi kepada yang lainnya dalam kelompok dan juga menguasai informasi anggota kelompok lainnya yang telah ditetapkan. Guru menilai penguasaan seluruh topik. Nilai individu diberikan berdasarkan atas ujian.

Menurut Budiadnyana (2004:21-22), pada metode pembelajaran kooperatif model jigsaw, setiap siswa dalam kelompok yang beranggotakan 5 orang diberikan informasi yang hanya menekankan satu bagian pelajaran. Setiap siswa dalam kelompok memperoleh potongan bacaan yang berbeda. Agar berhasil, semua siswa perlu mengetahui seluruh informasi tersebut. Siswa meninggalkan kelompok asal dan membentuk kelompok yang disebut 'kelompok ahli', di mana semua anggotanya membawa potongan informasi yang sama dan membahas bersama-sama, mempelajarinya dan memutuskan bagaimana cara terbaik untuk mengajarkan kepada temannya yang ada di kelompok asal. Setelah selesai, siswa kembali ke kelompok asal mereka dan setiap anggota mengajarkan apa yang menjadi bagian pelajarannya ke temannya yang lain dalam kelompok.

Adapun skema yang dimaksudkan sebagaimana tampak pada Gambar 1.

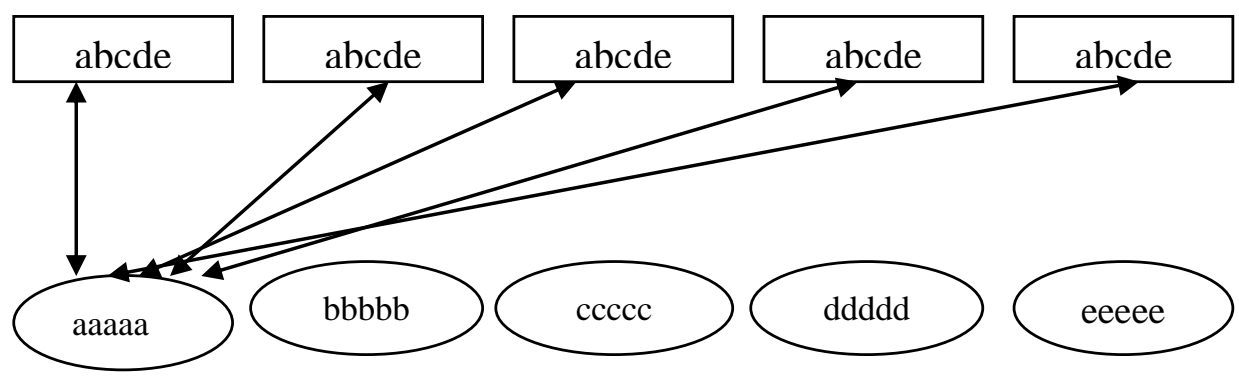

Base Group

Expert Group

\section{Gambar 1. Ilustrasi Kelompok Dasar dan Kelompok Ahli dalam Pembelajaran Kooperatif Model Jigsaw}

Siswa dikelompokkan menjadi kelompok dasar (base group), kemudian setiap anggota kelompok diberikan topik yang berbeda untuk dipelajari. Siswa dari kelompok dasar yang berbeda dengan topik yang sama dipertemukan dalam kelompok ahli (expert group) untuk berdiskusi dan membahas tugas materi yang ditugaskan pada masing-masing anggota kelompok serta membantu satu sama lain untuk mempelajari topik mereka tersebut. Para ahli kemudian kembali ke kelompok dasar masingmasing dan mengambil giliran untuk mengajar 
anggota kelompoknya (peer teaching) tentang topik mereka. Akhirnya siswa diberikan tes yang meliputi semua topik dan skor yang diperoleh dalam tes menjadi skor kelompok. Skor yang diperoleh kelompok didasarkan pada peningkatan skor dari setiap siswa. Peningkatan skor dilihat berdasarkan skor awal dan akhir yang diperoleh siswa. Skor awal adalah skor yang diperoleh siswa pada pembelajaran sebelumnya, sedangkan skor akhir adalah skor yang diperoleh dari tes pada model pembelajaran kooperatif tipe jigsaw.

Model pembelajaran kooperatif tipe jigsaw secara teoretis dapat mendorong dan mengkondisikan berkembangnya sikap dan keterampilan sosial siswa, meningkatkan hasil belajar dan secara empirik hanya diukur pada tingkat kognitif saja, serta aktivitas siswa. Karena keandalan penelitian model pembelajaran ini akan dibuktikan dalam penelitian ini.

Penelitian mengenai pengaruh belajar kooperatif terhadap prestasi belajar telah memajukan substansi mengenai belajar kooperatif. Kurang lebih 68 studi eksperimentalkontrol yang berkualifikasi sebagai masukan; hanya lima tahun setelah penelitian tersebut, terdapat 99 studi yang berkualitas, dan banyak yang lainnya membandingkan alternatif pendekatan kooperatif. Simpulan utama dari kajian ini sama seperti edisi dan pengkajipengkaji lainnya (seperti Davidson, 1995; Ellis \& Fouts, 1993; Newmann \& Thompson, 1997). Hadiah kelompok berdasarkan atas belajar individu dari semua anggota kelompok sangat penting dalam memproduksi hasil prestasi belajar yang positif dalam belajar kooperatif. Penelitian yang saat ini telah ditambahkan untuk simpulan dalam belajar kooperatif, bagaimanapun juga merupakan kemungkinan yang menjadi mungkin untuk menciptakan kondisi-kondisi yang membawa kepada hasil prestasi belajar yang positif melalui pengajaran siswa secara langsung yang disusun melalui metode kerja dengan anggota yang lainnya (teristimewa secara berpasangan) atau mengajar mereka strategi belajar yang menutup hubungan ke tujuan instruksional (teristimewa untuk pengajaran keterampilan pemahaman membaca) (Slavin, 1995: 45-46).

Penelitian pada belajar kooperatif menarik perhatian dalam hal ukuran dan kualitasnya. Masih banyak keadaan yang lainnya untuk dipelajari mengenai bagaimana, mengapa, dan di bawah kondisi apa belajar kooperatif meningkatkan prestasi belajar siswa, tetapi ini jelas bahwa di bawah keadaan batas-batas tertentu, belajar kooperatif dapat mempunyai kekonsistenan dan pengaruh penting terhadap belajar semua siswa. Dalam penelitian ini, model pembelajaran kooperatif tipe jigsaw diimplementasikan pada siswa kelompok kontrol. Hal ini disebabkan oleh model pembelajaran kooperatif tipe jigsaw relatif sering digunakan dalam proses belajar mengajar. Syntaks Pembelajaran Kooperatif Model Jigsaw: (a). Dimulai dengan penyajian materi, (b).Murid-murid digroupkan menjadi 4-5 orang, (c).Siswa mulai bekerja di timnya, setelah mendapat 4-5 pertanyaan, (d).Siswa membentuk tim ahli. Dalam hal ini guru memindahkan siswa. Siswa-siswa yang menjawab no 1 berkumpul denagn no 1 , yang menjawab no 2 berkumpul dengan yang menjawab no 2 dan seterusnya, (e).Siswa kembali ke tim mereka. Setelah mereka selesai bekerja di tim ahli mereka kembali ke groupnya masing-masing, (f).Evaluasi. (g).Memberi penghargaan. Penghargaan diberikan baik secara individu ataupun kelompok.

Prestasi belajar tidak mungkin dicapai atau dihasilkan oleh seseorang selama ia tidak melakukan kegiatan dengan sungguh-sungguh atau dengan perjuangan yang gigih. Dalam kenyataannya untuk mendapatkan prestasi tidak semudah membalikkan telapak tangan, tetapi harus penuh perjuangan dan berbagai rintangan dan hambatan yang harus dihadapi untuk mencapainya. Hanya dengan keuletan, kegigihan dan optimisme prestasi itu dapat tercapai. Setiap prestasi yang dihasilkan biasanya diawali dengan kegiatan belajar. Dari kegiatan inilah kemudian muncul suatu prestasi yang diperoleh setelah kurun waktu tertentu.

Dalam Kamus Besar Bahasa Indonesia, dinyatakan bahwa prestasi belajar adalah penguasaan pengetahuan atau keterampilan yang dikembangkan oleh mata pelajaran, lazimnya ditunjukkan dengan nilai tes atau angka nilai yang diberikan guru. Suratinah Tirtonegoro (1983: 43) menyebutkan bahwa prestasi belajar adalah hasil dari pengukuran serta penilaian usaha belajar. Memberi batasan prestasi belajar yaitu hasil usaha kegiatan belajar yang dinyatakan dalam bentuk simbol-simbol, huruf atau kalimat yang sudah dicapai oleh setiap peserta didik dalam setiap periode tertentu.

Menurut I.L Pasaribu dan B. Simanjuntak (1983:91) menyatakan bahwa "prestasi belajar adalah isi dan kapasitas seseorang. Maksudnya 
adalah hasil yang diperoleh seseorang setelah mengikuti pendidikan ataupun pelatihan tertentu. Ini bisa ditentukan dengan memberikan tes pada akhir pendidikan itu" Berdasarkan beberapa pendapat di atas dapat disimpulkan bahwa prestasi belajar merupakan hasil yang dicapai oleh individu setelah mengalami proses belajar dalam jangka waktu tertentu. Prestasi belajar yang ditampilkan dengan nilai atau angka dibuat guru berdasarkan pedoman penilaian pada masing-masing siswa berbeda, berdasarkan tingkat penguasaan kompetensi yang telah ditetapkan.

Rogers dengan teori pendidikan humanistiknya, mengemukakan prinsip-prinsip belajar yang diidentifikasikan sebagai sentral dari filsafat pendidikannya (Djiwandono, 1989: 184-186) sebagai berikut: (1).Keinginan untuk belajar (the desire to learn) Keingintahuan anak yang sudah melekat atau sudah menjadi sifatnya untuk belajar adalah asumsi dasar yang penting untuk pendidikan. Ini dapat dilihat ketika siswa mengeksplorasi lingkungannya. (2)Belajar secara signifikan (significant learning) Rogers menyatakan bahwa belajar secara signifikan terjadi ketika belajar dirasakan relevan terhadap kebutuhan dan tujuan siswa. (3).Belajar tanpa ancaman (learning without threat) Belajar yang paling baik adalah memperoleh dan menguasai suatu lingkungan yang bebas dari ancaman.siswa menguji kemampuan mereka, mencoba pengalaman baru, bahkan membuat kesalahanpun tanpa mengalami sakit hati karena kritik dan celaan. (4).Belajar atas inisiatif sendiri (self-initiated learning)Belajar paling signifikan dan meresap ketika belajar atas inisiatif sendiri, dan melibatkan perasaan dan pikiran si pelajar sendiri. (5).Belajar dan berubah (learning and change)Belajar paling bermanfaat adalah belajar tentang proses belajar. Bukan belajar satu set fakta dan ide, tetapi belajar dalam lingkungan yang terus berubah secara konstan

Sementara itu, prinsip-prinsip belajar yang dikemukakan oleh Slameto (2003: 27) adalah sebagai berikut: (a).Dalam belajar setiap siswa harus diusahakan partisipasi aktif, meningkatkan minat, dan membimbing untuk mencapai tujuan instruksional. (b).Belajar harus dapat menimbulkan motivasi yang kuat pada diri siswa. (c).Belajar perlu lingkungan yang menantang di mana anak dapat mengembangkan kemampuannya bereksplorasi dan belajar dengan efektif. (e).Belajar itu proses kontinyu, maka harus tahap demi tahap menurut perkembangannya.
Berdasarkan uraian di atas dapat disimpulkan bahwa prinsip-prinsip dalam belajar membutuhkan perhatian dan motivasi, keaktifan, pengulangan, keterlibatan langsung, balikan dan pengulangan supaya siswa dapat mencapai hasil yang baik. Disamping itu dalam belajar harus memperhatikan perbedaan individu, karena setiap siswa memiliki karakter yang berbeda satu dengan yang lain. Sehingga hal itu akan membantu siswa menentukan cara belajar dan sasaran belajar bagi dirinya sendiri

Dari pendapat para ahli tersebut dapat disimpulkan tujuan pembelajaran adalah perilaku hasil belajar yang diharapkan terjadi, dimiliki, atau dikuasai oleh siswa setelah mengikuti kegiatan pembelajaran tertentu. Tujuan pembelajaran dirumuskan dalam bentuk perilaku kompetensi spesifik, aktual, dan terukur sesuai yang diharapkan terjadi, dimiliki, atau dikuasai siswa setelah mengikuti kegiatan pembelajaran tertentu.

Kerangka berpikir di lihat berdasarkan pengalaman yang diperoleh siswa kelas VII.G SMP Negeri 1 Bintan, kegiatan siswa selama proses pembelajaran hanya sebatas mendengarkan dan menulis, sehingga siswa mengalami kesulitan dalam memahami materi. Selain itu, kegiatan pembelajaran dilakukan secara klasikal berpusat pada guru. Pengalaman belajar siswa dalam belajarpun tidak banyak. Akibatnya, siswa tidak terlatih untuk dapat menemukan, dan memeahkan masalah secara kritis dan kreatif di kelas.

Kemampuan menampilkan sesuatu yang baik tentu memerlukan bimbingan orang lain, dalam hal ini adalah bimbingan guru terhadap siswanya. Apabila guru telah melakukan inovasi-inovasi untuk mematangkan siswanya memperoleh kemampuan yang diharapkan dalam menampilkan sesuatu tentu dapat diharapkan para siswa akan memiliki kebiasaankebiasaan, keterampilan-keterampilan yang dibutuhkan. Untuk dapat terwujudnya apa yang diharapkan tersebut, inovasi langkah-langkah yang diupayakan guru akan dapat memecahkan permasalahan yang ada. Atas dasar hal tersebut maka peneliti mencoba untuk menggunakan model pembelajaran Cooperative Learning Tipe Jigsaw pada pelajaran Bahasa Indonesia materi cerita fantasi di kelas VII.G SMP Negeri 1 Bintan.

Hipotesis tindakan merupakan suatu tindakan yang diduga akan dapat memecahkan masalah yang ingin diatasi. Mengacu pada teori yang disampaikan, rumusan hipotesis dapat 
disampaikan apabila Penggunaan model pembelajaran kooperatif tipe jigsaw untuk meningkatkan prestasi belajar Bahasa Indonesia siswa kelas VII.G SMP Negeri 1 Bintan.

\section{METODE PENELITIAN}

Jenis penelitian ini adalah penelitian tindakan kelas (PTK) yaitu penelitian yang dilakukan dalam kelas oleh guru melalui refleksi diri dengan tujuan untuk memperbaiki kinerjanya sebagai guru, sehingga hasil belajar siswa menjadi meningkat. Pelaksanaan PTK merupakan suatu siklus, dalam penelitian ini model siklus mengikuti model Kurt Lewin seperti disampaikan pada gambar berikut:

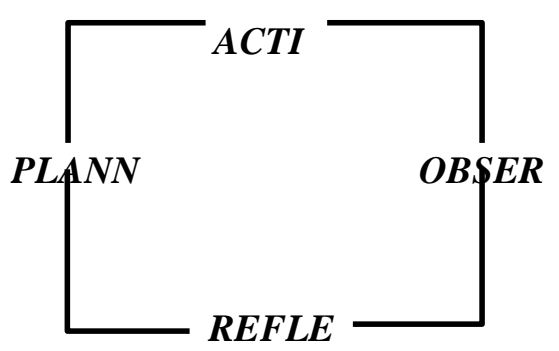

Gambar 2. Diagram Kancangan Penelitian dalam Kurt Lewin (dalam Hamzah B. Uno, dkk: 2011:86)

Apabila dicermati rancangan yang dibuat para ahli sangat penting dijadikan pedoman dalam melaksanakan penelitian. Prosedur pelaksanaannya tentu saja mengikuti alur rancangan para ahli. Dalam penelitian ini yang diikuti adalah rancangan atau gambar yang dibuat oleh Kurt Lewin, sehingga prosedur yang diikuti adalah mulai dengan perencanaan, selanjutnya tindakan atau acting, selanjutnya observasi dan terakhir refleksi. Subjek penelitian ini adalah siswa Kelas VII/G SMP Negeri 1 Bintan Tahun Pelajaran 2019/2020 berjumlah 31 orang, objek penelitian adalah peningkatan prestasi belajar siswa kelas VII.G SMP Negeri 1 Bintan. Data Prestasi belajar dianalisis secara deskritif kualitatif.

Untuk menuntaskan tahapan tindakan dari perencaaan, pelaksanaan, observasi, dan refleksi akan dilakukan penentuan batas waktu sesuai perencanaan. Agar lebih sistematis dan terencana, peneliti perlu menyusunnya menjadi jadwal yang sistematis dan terusun dengan baik. Dalam penelitian ini jadwal pelaksanaantindakan akan dilakukan dari bulan Juli sampai Desember 2019.

Hasil belajar yang diharapkan dalam penelitian ini dikumpulkan dengan memberikan tes prestasi belajar kepada siswa. Instrumen tes prestasi belajar siswa tertulis pada dalam RPP. Sedangkan untuk menganalisis data yang diperoleh dari penelitian ini digunakan metode deskriptif. Untuk data kuantitatif dianalisis dengan mencari mean, median, modus, membuat interval kelas dan melakukan penyajian dalam bentuk tabel.

Indikator keberhasilan pada penelitian ini adalah jika prestasi belajar siswa sudah mengalami peningkatan pada siklus selanjutnya maka penelitian ini sudah dianggap berhasil. Sebagai acuan untuk membuat butir-butir tes yang digunakan guru untuk mengumpulkan data yang dipergunakan dalam penelitian ini maka disusunkan kisi-kisi instrumen, seperti yang terlihat pada tabel berikut.

\section{Hasil Penelitian}

Kunandar (2008:208-209) menjelaskan bahwa pada hasil dan pembahasan peneliti memaparkan apa yang direncanakan di siklus I, apa yang dilaksanakan, bagaimana hasil observasi dan pada refleksi disetiap siklus berisi penjelasan tentang aspek keberhasilan dan kelemahan yang terjadi. Paparan pada siklus II juga lengkap mulai perencanaan, pelaksanaan observasi, dan evaluasi.

Hasil belajar siswa pada siklus I dapat dilihat pada Grafik berikut.

Tabel 1. Kisi-Kisi Tes Prestasi Belajar

\begin{tabular}{|c|c|c|c|c|c|}
\hline No & $\begin{array}{c}\text { Standar } \\
\text { Kompetensi }\end{array}$ & Kompetensi Dasar & Materi & Indikator & Bentuk Tes \\
\hline 1. & & $\begin{array}{l}\text { Mengidentifikasi } \\
\text { unsur-unsur teks } \\
\text { narasi (cerita fantasi) } \\
\text { yang dibaca dan } \\
\text { didengar }\end{array}$ & $\begin{array}{l}\text { Cerita } \\
\text { Fantasi }\end{array}$ & $\begin{array}{l}\text { Menjelaskan } \\
\text { pengertian dan } \\
\text { memahami jenis } \\
\text { cerita fantasi serta } \\
\text { dapat menyebutkan } \\
\text { beberapa }\end{array}$ & Tes Tulis \\
\hline
\end{tabular}


contohnya

\begin{tabular}{ll}
\hline 2. & $\begin{array}{l}\text { Menyimpulkan ciri Tes Tulis } \\
\text { umum cerita fantasi }\end{array}$ \\
\hline 3. & $\begin{array}{l}\text { Memahami unsur Tes Tulis } \\
\text { intrinsik cerita } \\
\text { fantasi }\end{array}$ \\
\hline 4. & $\begin{array}{l}\text { Menemukan } \\
\text { unusur intrinsik } \\
\text { pada cerita fantasi } \\
\text { dan menunjukkan } \\
\text { bukti pada teks }\end{array}$
\end{tabular}

\begin{tabular}{llll}
\hline 5. & Menelaah struktur Cerita & $\begin{array}{l}\text { Memahami struktur } \\
\text { cerita fantasi }\end{array}$ & Tes Tulis \\
& dan kebahasaan teks Fantasi & \\
& narasi (cerita fantasi) & \\
& yang ddibaca dan & & \\
& didengar
\end{tabular}

\begin{tabular}{ll}
\hline 6. & $\begin{array}{l}\text { Memahami variasi Tes Tulis } \\
\text { pengungkapan } \\
\text { satruktur cerita } \\
\text { fantasi }\end{array}$ \\
\hline 7. & $\begin{array}{l}\text { Memahami ciri Tes Tulis } \\
\text { kebahasaan cerita } \\
\text { fantasi }\end{array}$ \\
\hline 8. & $\begin{array}{l}\text { Menemukan Tes Tulis } \\
\text { struktur dan unsur } \\
\text { bahasa pada cerita } \\
\text { fantasi yang } \\
\text { dibaca. }\end{array}$ \\
\hline
\end{tabular}

\section{HASIL PENELITIAN DAN PEMBAHASAN}

\section{Hasil Penelitian}

Kunandar (2008:208-209) menjelaskan bahwa pada hasil dan pembahasan peneliti memaparkan apa yang direncanakan di siklus I, apa yang dilaksanakan, bagaimana hasil observasi dan pada refleksi disetiap siklus berisi penjelasan tentang aspek keberhasilan dan kelemahan yang terjadi. Paparan pada siklus II juga lengkap mulai perencanaan, pelaksanaan observasi, dan evaluasi.

\section{Siklus I}

Rencana Tindakan I. Dalam perencanaan terlihat dengan jelas alur yang harus diikuti oleh seorang peneliti. Perencaan meliputi: (1) Merencanakan alat pelajaran yang bervariasi; (2) Merencanakan pembelajaran yang menyenangkan; (3) Merencanakan pembelajaran yang membangkitkan minat belajar; (4) Merencanakan pembelajaran yang memotivasi siswa agar berperan aktif; (5) Merencanakan kegiatan tanya jawab multi arah agar semua siswa mendapat kesempatan berpartisipasi aktif

Pelaksanaan Tindakan I. Pelaksanaan penelitian mesti dilakukan dengan genap sesuai tujuan yang hendak dicapai sesuai tujuan penelitian ini, maka peneliti melaksanakan dengan: (1) Membawa semua persiapan ke kelas; (2) Memasuki kelas dengan mengucapkan 
salam; (3) Mengatur tempat duduk yang rapi; (3) Menciptakan suasana belalajar yang nyaman; (4) Menjelaskan tujuan pembelajaran serta cakupan materi yang akan diajari; (5) Melakasanakan kegiatan inti sesuai dengan yang teruang dalam RPP dengan menggunakan model pembelajaran Kooperatif Jigsaw melalui metode diskusi

Observasi/Pengamatan Siklus I. Dalam melakukan observasi peneliti melakukan penilaian terhadap kemampuan subjek yaang diteliti. Untuk itu yang dilakukan adalah: (1) Masuk ke kelas dengan membawa lembar observasi/pengamatan, dengan mengucapkan salam, berlanjut dengan memberi penjelasan tentang tes yang harus dikerjakan, membagikan tes serta lembar kertas yang digunakan untuk menjawab soal-soal tes pada siswa; (2) Memberi kesempatan pada siswa untuk menandatangani absen kehadiran ikut tes; (3) Semua tes yang telah dipersiapkan mengacu pada indikator dan komptensi siswa yang ingin diukur; (4) Mengawasi pelaksanaan tes agar siswa tidak bekerjasama untuk memperoleh data yang valid atau dapat dipertanggungjawabkan keabsahannya. Bagi siswa yang mencapai ketuntasan belajar yang ditetapkan, pada hasil tes diberikan motivasi dan dorongan untuk terus meraih prestasi yang lebih baik, sedangkan bagi siswa yang belum meraih KKM guru menyampaikan saran dan motivasi agar siswa lebih giat dan rajin, serta lebih fokus pada apa yang dipelajari.

Refleksi Siklus I. Refleksi merupakan kajian secara menyeluruh tindakan yang telah dilakukan berdasarkan data yang telah terkumpul, kemudian dilakukan evaluasi guna menyempurnakan tindakan. Refleksi menyangkut analisis, sintesis, dan penilaian terhadap hasil pengamatan atas tindakan yang dilakukan (Hopkin, 1993 dalam Suharsimi Arikunto, Suhardjono, Supardi, 2006: 80).

Tabel 2. Data Kelas Interval Siklus I

\begin{tabular}{ccccc}
\hline $\begin{array}{c}\text { No } \\
\text { Urut }\end{array}$ & Interval & $\begin{array}{c}\text { Nilai } \\
\text { Tengah }\end{array}$ & $\begin{array}{c}\text { Frekuensi } \\
\text { Absolut }\end{array}$ & $\begin{array}{c}\text { Frekuensi } \\
\text { Relatif }\end{array}$ \\
\hline 1 & $40-50$ & 44,5 & 7 & 22.58 \\
\hline 2 & $51-60$ & 54,5 & 9 & 29.03 \\
\hline 3 & $61-70$ & 64,5 & 4 & 12.90 \\
\hline 4 & $71-70$ & 74,5 & 2 & 6.45 \\
\hline 5 & $81-90$ & 84,5 & 4 & 12.90 \\
\hline 6 & $91-100$ & 94,5 & 5 & 16.13 \\
\hline \multicolumn{5}{c}{ Total } \\
\hline
\end{tabular}

Kekurangan-kekurangan/kelemahan-

kelemahan yang ada dari pelaksanaan tindakan siklus I adalah: (1) Kemamuan siswa untuk menyelesaikan tugas-tugas yang disuruh masih rendah; (2) Siswa masih berpikir bahwa mata pelajaran yang diajarkan adalah mata pelajaran yang sulit dan membosankan; (3) Dengan strategi yang berbeda siswa masih menunggu perintah guru; (4) Kurang mampunya guru memberi umpan balik penguatan; (5) Media pembelajaran belum mampu diterapkan secara maksimal.

Sedangkan kelebihan yang ditemukan pada pelaksanaan tindakan siklus I adalah: (1) Kebiasaan peserta didik aktif bekerja mampu ditingkatkan dengan cara ini; (2) Model yang baru mampu mengassah kemampuan mereka dalam berdiskusi, bertukar pendapat.

\section{Siklus II}

Rencana Tindakan II. Harapan akan keberhasilan sebuah penelitian bisa diupayakan lewat perencanaan yang matang. Perencanaan yang dibuat adalah: (1) Membuat perencanaan menggunakan metode yang bervariasi agar tidak membosankan; (2) Merencanakan pembelajaran yang interaktif; (3) Merencanakan pembelajaran yang memotivasi siswa agar aktif berperan; (4) Merencanakan adanya kompetensi dalam kegiatan tanya jawab sehingga tidak ada peserta didik yang pasif

Pelaksanaan Tindakan II. Pelaksanaan penelitian ini telah didahului dengan penyusunan perencanaan. Perencanaan yang telah disusun dengan baik menjadi dasar dalam melaksanakan penelitian ini untuk itu peneliti melaksanakan hal-hal: (1) Mengajar sesuai langkah-langkah model kooperatif jigsaw dengan metode diskusi sesuai teori; (2) Mencatat kreativitas siswa dalam mengikuti pembelajaran; (3) Menyampaikan bahan-bahan lain pendukung pembelajaran pada siswa agar materi dapat dibaca dari berbagai sumber; (4) Melakukan penilaian proses; (5) Menyampaikan pada peserta didik bahwa tes akan diberkan pada pertemuan selanjutnya.

Observasi/Pengamatan Siklus II. Observasi atau pengumpulan data dari kegiatan penelitian ini dilakukan dengan cara: (1) Melakukan penelitian hasil tes yang dilakukan siswa secara seksama untuk mendapatkan nilai yang diharapkan; (2) Menjelaskan bahwa prinsip pembelajaran remedial didasarkan atas pertimbangan prinsip-prinsip pembelajaran tuntas; (3) Menjelaskan tentang tes yang akan diberikan pada siswa 
Refleksi merupakan kajian secara menyeluruh tindakan yang telah dilakukan berdasarkan data yang telah terkumpul, kemudian dilakukan evaluasi guna menyempurnakan tindakan. Refleksi menyangkut analisis, sintesis, dan penilaian terhadap hasil pengamatan atas tindakan yang dilakukan (Hopkin, 1993 dalam Suharsimi Arikunto, Suhardjono, Supardi, 2006: 80).

Tabel 3. Kelas Interval Siklus II

\begin{tabular}{ccccc}
\hline $\begin{array}{c}\text { No } \\
\text { Urut }\end{array}$ & Interval & $\begin{array}{c}\text { Nilai } \\
\text { Tengah }\end{array}$ & $\begin{array}{c}\text { Frekuensi } \\
\text { Absolut }\end{array}$ & $\begin{array}{c}\text { Frekuensi } \\
\text { Relatif }\end{array}$ \\
\hline 1 & $60-66$ & 63 & 14 & 45.16 \\
\hline 2 & $67-73$ & 70 & 4 & 12.90 \\
\hline 3 & $74-80$ & 77 & 2 & 6.45 \\
\hline 4 & $81-87$ & 84 & 1 & 3.23 \\
\hline 5 & $88-94$ & 91 & 2 & 6.45 \\
\hline 6 & $95-100$ & 97 & 8 & 25.81 \\
\hline & Total & & 31 & 100 \\
\hline
\end{tabular}

Kekurangan-kekurangan/kelemahankelemahan yang ada dari pelaksanaan tindakan siklus II adalah: (1) Belum pahamnya peneliti akan model-model baru yang bersifat lebih konstruktivis; (2) Siswa belum mampu menghubungkan materi yang mereka pelajari dengan pemanfaatannya dalam kehidupan nyata. Sedangkan kelebihan yang ditemukan pada pelaksanaan tindakan siklus II adalah: (1) Tanya jawab sudah dilakukan melalui tanya jawab multi arah; (2) Pembelajaran telah diupayakan dengan membangkitkan keinginan; (3) Persiapan peserta didik dalam berprestasi di depan kelas sudah maksimal; (4) Penjelasan guru telah diupayakan yang bervariasi; (5)Siswa menjadi percaya diri dalam berkomunikasi.

\section{Pembahasan Penelitian}

Pembahasan hasil yang diperoleh dari Siklus I adalah hasil tes prestasi belajar yang merupakan tes tertulis memforsir siswa untuk betul-betul dapat memahami apa yang sudah dipelajari. Nilai rata-rata siswa di siklus I sebesar 68,87 menunjukkan bahwa siswa setelah menguasai materi yang diajarkan walaupun belum begitu sempurna. Hasil ini menunjukkan peningkatan kemampuan siswa menguasai mata pelajaran Bahasa Indonesia. Apabila dibandingkan dengan nilai awal siswa sesuai data yang sudah disampaikan dalam analisis sebelumnya.

Hasil tes prestasi belajar di siklus I telah menemukan efek utama bahwa penggunaan model tertentu akan berpengaruh terhadap prestasi belajar siswa yang dalam hal ini adalah model kooperatif tipe Jigsaw. Hal ini sesuai dengan hasil meta analisis metode pembelajaran yang dilakukan oleh Soedomo, 1990 (dalam Puger, 2004) yang menyatakan bahwa model pembelajaran yang diterapkan oleh seorang guru berpengaruh terhadap prestasi belajarnya.

Seperti telah diketahui bersama bahwasannya mata pelajaran Bahasa Indonesia menitikberatkan pembelajaran pada aspek kognitif, afektif, dan psikomotorik sebagai pedoman prilaku kehidupan sehari-hari siswa. Untuk penyelesaian kesulitan yang ada maka penggunaan model ini dapat membantu siswa untuk bertindak aktif, kreatif dan inovatif dalam berpikir, menyampaikan pendapat dan pikiran individu, memecahkan masalah yang ada bersama dengan anggota kelompok diskusinya. Hal inilah yang membuat siswa berpikir lebih tajam, lebih kreatif dan kritis sehingga mampu untuk memecahkan masalah-masalah yang kompleks dan efek selanjutnya adalah para siswa akan dapat memahami dan meresapi mata pelajaran Bahasa Indonesia lebih jauh.

Kendala yang masih tersisa yang perlu dibahas adalah prestasi belajar yang dicapai pada siklus I ini belum memenuhi harapan sesuai dengan tuntutan KKM mata pelajaran Bahasa Indonesia di sekolah ini yaitu 63. Oleh karenanya upaya perbaikan lebih lanjut masih perlu diupayakan sehingga perlu dilakukan perencanaan yang lebih matang untuk siklus selanjutnya.

Pembahasan hasil yang diperoleh dari Siklus II adalah hasil yang diperoleh dari tes prestasi belajar di siklus II menunjukkan bahwa kemampuan siswa dalam mengikuti pelajaran sudah cukup baik. Ini terbukti dari rata-rata nilai siswa mencapai77,10. Hasil ini menunjukkan bahwa model kooperatif tipe Jigsaw telah 
berhasil meningkatkan prestasi belajar bidang studi bahasa Indonesia.

Hasil penelitian ini membuktikan bahwa model yang diterapkan dalam proses pembelajaran berpengaruh secara signifikan terhadap prestasi belajar siswa. Prestasi yang dicapai siswa membuktikan bahwa guru sudah tepat memilih model dalam melaksanakan proses pembelajaran. Setelah dilakukan tindakan dalam dua siklus dapat dilihat perbandingan nilai rata-rata yang diperoleh, dimana pada awalnya nilai rata-rata siswa hanya 63,87 naik di siklus I menjadi 68,87 dan di siklus II naik menjadi 77,10 . Kenaikan ini merupakan upaya maksimal yang peneliti laksanakan untuk meningkatkan prestasi belajar siswa terutama meningkatkan mutu pendidikan di SMP Negeri 1 Bintan.

\section{SIMPULAN DAN SARAN Simpulan}

Dari hasil refleksi yang telah disampaikan dengan melihat semua data yang telah dipaparkan, dapat disampaikan bahwa pencapaian tujuan penelitian di atas dapat dibuktikan dengan argumentasi sebagai berikut. (1) Dari data awal ada 18 siswa mendapat nilai di bawah KKM dan pada siklus I menurun menjadi 16 siswa dan siklus II hanya 5 siswa mendapat nilai di bawah KKMNilai rata-rata awal 63,87 naik menjadi 68,87 pada siklus I dan pada siklus II naik menjadi 77,10; (2) Dari data awal siswa yang tuntas hanya 13 orang sedangkan pada siklus I menjadi lebih banyak yaitu 15 siswa dan pada siklus II menjadi cukup banyak yaitu 26 siswa. Paparan di atas membuktikan bahwa model kooperatif Jigsaw dengan menggunakan metode diskusi dapat memberi jawaban sesuai tujuan penelitian ini. Semua ini dapat dicapai karena model/metode tersebut sangat efektif diterapkan dalam proses pembelajaran yang mengakibatkan siswa aktif, antusias dan dapat memahami materi yang diajarkan sehingga prestasi belajar siswa menjadi meningkat.

\section{Saran}

Bagi guru kelas, apabila mau melaksanakan proses pembelajaran penggunaan model yang telah diterapkan ini semestinya menjadi pilihan dari beberapa model yang ada mengingat model ini telah terbukti dapat meningkatkan prestasi belajar siswa. Bagi peneliti lain, walaupun penelitian ini sudah dapat membuktikan efek utama dari model kooperatif Jigsaw dalam meningkatkan prestasi belajar, sudah pasti dalam penelitian ini masih ada hal-hal yang belum sempurna dilakukan, oleh karenanya disarankan kepada peneliti lain yang berminat meneliti topik yang sama untuk meneliti bagian-bagian yang tidak sempat diteliti. Bagi pengembang pendidikan, selanjutnya untuk adanya penguatan-penguatan, diharapkan bagi peneliti lain untuk melakukan penelitian lanjutan guna memverifikasi data hasil penelitian ini.

\section{DAFTAR PUSTAKA}

Abdul.2002.http://www.scribd.com/doc/903720 8/

Arikunto, Suharsimi; Suhardjono; Supardi. 2006. Penelitian Tindakan Kelas. Jakarta: PT Bumi Aksara.

Dahar, Ratna Wilis. 1989. Teori-Teori Belajar. Jakarta: Penerbit Erlangga.

Lie, Anita. 2002. Cooperative Learning: Mempraktikkan Cooperative Learning di Ruang-Ruang Kelas. Jakarta: PT Gramedia Widiasarana Indonesia.

Puger, I Gusti Ngurah. 2004. Belajar Kooperatif. Diktat Perkuliahan Mahasiswa Unipas.

Slameto. 2000. Belajar dan Faktor-Faktor yang Mempengaruhinya. Jakarta: Rineka Cipta.

Slavin, Robert E. 1995. Cooperative Learning : Theory, Research, and Practice. Boston: Allyn and Bacon.

Sriyono.1992.http://www.scribd.com/doc/90372 $\underline{081}$

Tim Redaksi Fokus Media. 2006. Himpunan Perundang-Undangan dan UndangUndang Republik Indonesia No. 20 Tahun 2003 dan Peraturan Pemerintah No. 19 Tahun 2005. Bandung: Focus Media

Uno, B. Hamzah, et. al. 2001. Pengembangan Instrumen Untuk Penelitian. Jakarta: Delima Press. 